\title{
Correction to: Synthesis, molecular docking, and apoptogenic efficacy of novel N-heterocycle analogs to target B-cell lymphoma 2/X-linked inhibitors of apoptosis proteins to regress melanoma
}

\author{
Zabiulla $^{1} \cdot$ Vikas H. Malojirao ${ }^{2} \cdot$ Yasser Hussein Eissa Mohammed ${ }^{1} \cdot$ Prabhu Thirusangu $^{3} \cdot$ B. T. Prabhakar ${ }^{2} \cdot$ \\ Shaukath Ara Khanum ${ }^{1}$
}

Published online: 22 July 2019

(c) Springer Science+Business Media, LLC, part of Springer Nature 2019

\section{Correction to:}

Medicinal Chemistry Research (2019) 28:1132-1160

https://doi.org/10.1007/s00044-019-02357-x

The original version of this article unfortunately contained an error in author group. The first author name was repeated twice. The correct name is Zabiulla instead it was published incorrectly as Zabiulla Zabiulla.

The original article can be found online at https://doi.org/10.1007/ s00044-019-02357-x.

B. T. Prabhakar

prabhakarbt@gmail.com

$\bowtie$ Shaukath Ara Khanum

shaukathara@yahoo.co.in

1 Department of Chemistry, Yuvaraja's College (Autonomous),

University of Mysore, Mysore, Karnataka, India

2 Molecular Biomedicine Laboratory, Postgraduate Department of Studies and Research in Biotechnology, Sahyadri Science College, Kuvempu University, Shimoga, Karnataka, India

3 Department of Experimental Pathology and Medicine, Mayo Clinic, Rochester, MN 55902, USA 